\title{
FEEDING DYNAMICS OF LARVAL PACIFIC HERRING \\ (CLUPEA PALLASI) ON NATURAL PREY ASSEMBLAGES: \\ THE IMPORTANCE OF PROTISTS
}

By

\section{LAURA ELIZABETH FRIEDENBERG}

A thesis submitted in partial fulfillment of the requirements for the degree of

MASTER OF SCIENCE IN ENVIRONMENTAL SCIENCE

WASHINGTON STATE UNIVERSITY VANCOUVER

School of Earth and Environmental Science

DECEMBER 2009 
To the faculty of Washington State University:

The members of the Committee appointed to examine the thesis of LAURA ELIZABETH FRIEDENBERG find it satisfactory and recommend that it be accepted.

Stephen M. Bollens, Ph.D., Chair

$\overline{\text { Gretchen C. Rollwagen-Bollens, Ph. D. }}$

Brian N. Tissot, Ph. D.

Stephen M. Henderson, Ph. D. 


\section{ACKNOWLEDGEMENTS}

I would like to thank P. Hershberger and J. Gregg of the USGS Marrowstone Marine Field station for the use of lab space and logistical support. Thanks to C. Ross, A. Gibson, and G. Rollwagen-Bollens for plankton identification assistance. Additionally, thanks to G.

Rollwagen-Bollens for assistance with data processing. Special thanks to the WSUV aquatic ecology lab staff and graduate students for support and guidance. Additionally, thanks to S. Bollens and G. Rollwagen-Bollens for their comments on early versions of the manuscript, and finally thanks to B. Tissot and S. Henderson for their participation in this process. Support for this research was provided by Washington State University Vancouver and an NSF GK-12 Fellowship (NSF Award \# 07-42561 to G.R.B). 


\title{
FEEDING DYNAMICS OF LARVAL PACIFIC HERRING \\ (CLUPEA PALLASI) ON NATURAL PREY ASSEMBLAGES: \\ THE IMPORTANCE OF PROTISTS
}

\author{
Abstract \\ by Laura Elizabeth Friedenberg, M.S. \\ Washington State University Vancouver \\ December 2009
}

Chair: Stephen M. Bollens

The role of protists in the diet of larval Pacific herring (Clupea pallasi) was examined using a natural assemblage of microplankton $(10-200 \mu \mathrm{m})$ in laboratory incubations in May and June of 2008. Available prey consisted of protists (diatoms, dinoflagellates, aloricate ciliates, and loricate ciliates) and metazoans (trochophores, bivalve larvae, rotifers, copepod nauplii, and gastropod larvae). We used a prey enumeration technique that included soft-bodied heterotrophic protists (aloricate ciliates and athecate dinoflagellates) in the diet. We observed significant consumption of aloricate ciliates, loricate ciliates, bivalve larvae, dinoflagellates, and 73-200 $\mu \mathrm{m}$ available prey. Clearance rates $\left(\mathrm{ml} \mathrm{larva}^{-1} \mathrm{~h}^{-1}\right)$ were used as a measure of prey selectivity. The herring larvae showed strong selection for bivalve larvae and 73-200 $\mu \mathrm{m}$ available prey. Protists were selected for at rates comparable to metazoans. Ingestion rates ( $\mu \mathrm{g}$ $\mathrm{C}$ larva ${ }^{-1} \mathrm{~h}^{-1}$ ) showed that the majority of larval carbon intake was from diatoms and aloricate ciliates. The results of this study illustrate that there is a direct trophic link between larval 
herring and the microbial loop, and protists may comprise a substantial portion of the larval fish diet, possibly alleviating food limitation. 


\section{TABLE OF CONTENTS}

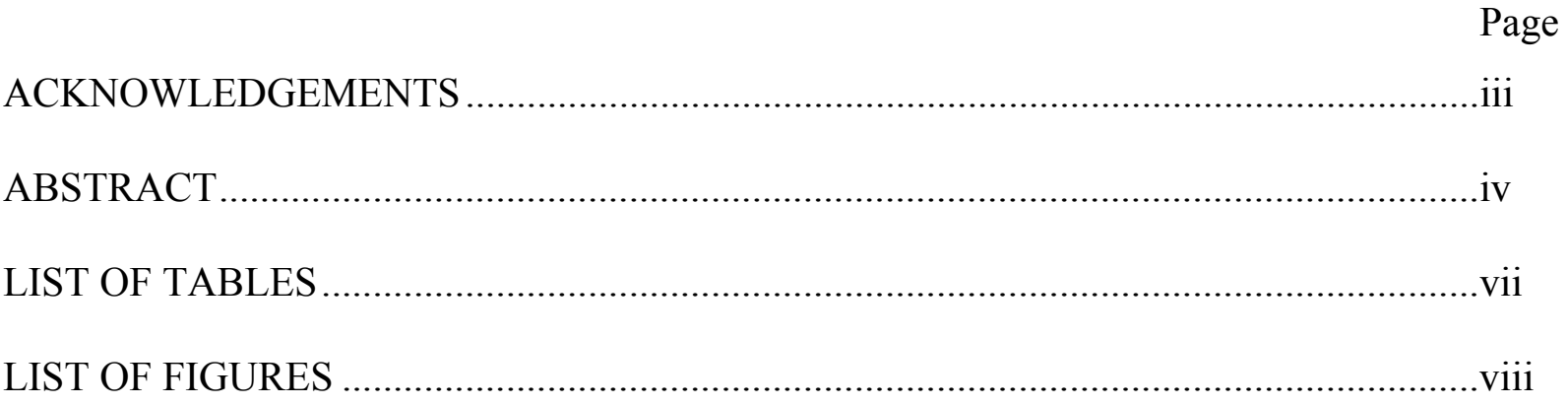

\section{CHAPTER}

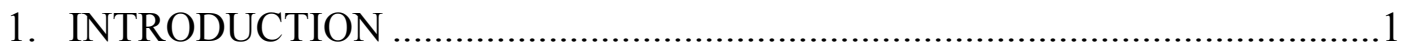

2. MATERIALS AND METHODS

a. LARVAL HERRING FEEDING EXPERIMENTS ............................4

b. CELL COUNTS AND BIOMASS ESTIMATIONS............................6

c. CLEARANCE AND INGESTION RATE CALCULATIONS...............7

d. DATA ANALYSIS ...................................................................... 7

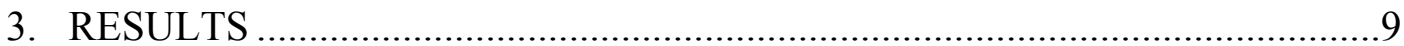

a. AVAILABLE PREY COMPOSITION, SIZE, ABUNDANCE AND

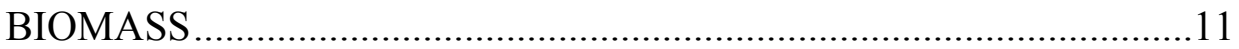

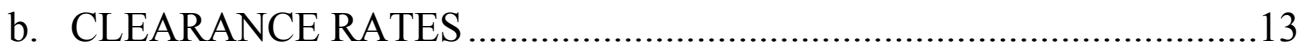

c. INGESTION RATES..................................................................... 18

4. DISCUSSION

a. LARVAL HERRING DIET AND SELECTIVITY …..........................23

b. LARVAL PRECONDITIONING AS A SOURCE OF VARIATION....25

c. LARVAL HERRING INGESTION ..................................................26

d. IMPLICATIONS AND SUMMARY ............................................28 


\section{LIST OF TABLES}

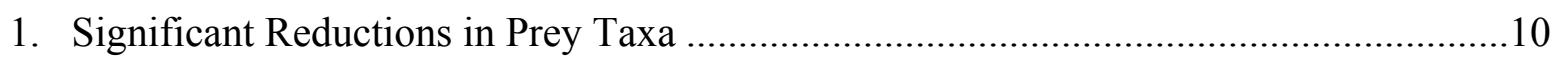




\section{LIST OF FIGURES}

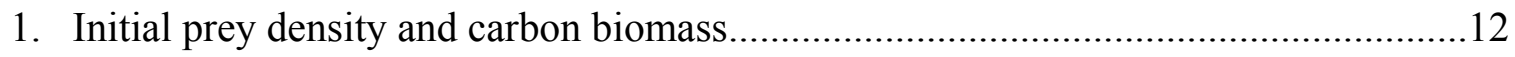

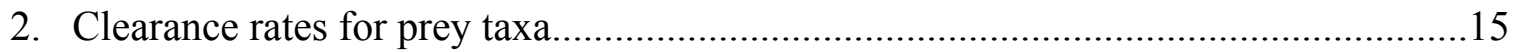

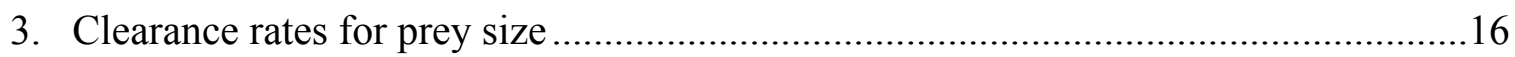

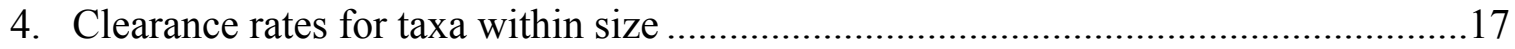

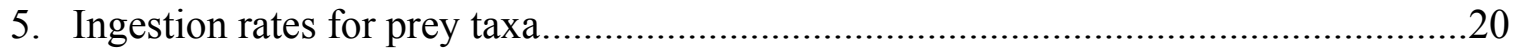

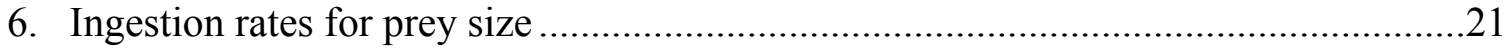

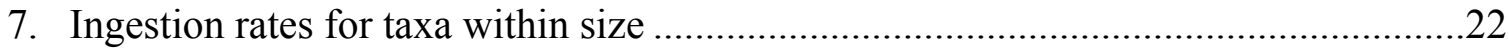




\section{CHAPTER ONE}

\section{INTRODUCTION}

Fish are most vulnerable and experience the highest degree of mortality during the larval stage after the yolk sac is absorbed (Houde 1989, Fiksen \& Foldvord 1999). A major source of larval death is starvation due to feeding failure or inadequate nutritional quality of prey items (Hjort 1914, Cushing 1975, Lasker 1975). First-feeding larval fish are traditionally recognized as zooplanktivores, consuming primarily metazoans (multicellular eukaryotes), such as calanoid copepod nauplii, copepodites, and invertebrate larvae (Arthur 1976, Last 1978a, b, Munk \& Kiorboe 1985). However, the diet of larval fish is determined by prey availability, prey escape response, and larval gape size in relation to prey size (Checkley 1982, Figueiredo et al. 2007). If larvae do not have access to, or can not ingest large, nutritious prey items, they may consume smaller, slower, nutritionally poor, more abundant prey, such as protists (single-celled autotrophic, heterotrophic and mixotrophic eukaryotes, e.g. diatoms, ciliates and dinoflagellates), in order to survive. Consumption of protists may alleviate food limitation of larval fish (Stoecker

\& Capuzzo 1990, Hunt von Herbing \& Gallager 2000), and may allow for growth and survival of the larvae until they either encounter larger zooplankton or until their gape size can accommodate large prey (Nagano et al. 2000, Figueiredo et al. 2007). Additionally, larval fish may have a poor digestive capacity at the onset of feeding, and protists may provide a food source that is assimilated easier than copepodites and invertebrate nauplii (Reitan et al. 1998).

An increasing body of literature identifies larval fish as a link between pelagic and microbial food webs. Laboratory and field studies involving gut content analysis of first-feeding larval fish show that a wide variety of prey items are consumed, including protists, and as larvae grow they become more selective and target larger prey items (Arthur 1976, Checkley 1982, 
Bollens \& Sanders 2004). For instance, tintinnid ciliates, heterotrophic protists with a hard lorica surrounding the body, have been found in the guts of seven species of larval fish in the English Channel and the North Sea (Last 1978a, b), larval Pacific herring from the San Francisco Estuary (Bollens \& Sanders 2004), 11 taxa of larval fish from the Irish Sea (Figueiredo et al. 2007), and 46 taxa of larval fish from Tosa Bay, Japan (Fukami et al. 1999). Laboratory investigations using gut content analysis methods have also shown that larval fish consume protists (Figueiredo et al. 2007). However, examination of gut contents only reveals empty lorica of tintinnid ciliates, or at best unidentifiable soft-bodied protist cells, as evidence of protist consumption. These laboratory and field studies draw attention to an aspect of larval fish diet and food limitation that has been previously overlooked, but do not provide a quantitative measure of the degree to which larval fish may select for protists or their rates of ingestion of these prey.

Gut content analysis is only adequate for identifying prey items with hard parts, such as lorica (ciliates) or theca (dinoflagellates). Organisms that lack hard parts (e.g. aloricate ciliates and athecate dinoflagellates) digest rapidly, and are not identifiable in the gut contents (Spittler et al. 1990, Nagano et al. 2000, Figueiredo et al. 2007). Even if all prey items were discernable in the gut contents, there is often a high percentage of empty guts sampled as a result of regurgitation and/or defecation during the sampling process, which leads to an underestimation of prey available to fish larvae (Figueiredo et al. 2005, Pepin \& Dower 2007). Several targeted studies have found heterotrophic protists in the guts of larval fish by labeling protists with protist-specific immunofluorescent antibody probes (Ohman et al. 1991), the fluorescent DNAspecific stain DAPI (Lessard et al. 1996), and fluorescent microspheres (Nagano et al. 2000). Protist consumption by larval fish has also been observed by the tracing of lipid biomarkers 
(Rossi et al. 2006), video observations of feeding events (Hunt von Herbing \& Gallager 2000), and detection of aloricate ciliate DNA in guts of larval fish collected from the field using epifluorescence microscopy (Fukami et al. 1999). However, these studies were limited in their results and did not address selectivity and ingestion of the larvae on protist prey, and the prey assemblage in the laboratory studies consisted only of protists.

Another approach, used in crustacean zooplankton studies but not thus far with larval fish, is to examine natural assemblages of both soft-bodied and hard-bodied prey before and after incubation with predators (Rollwagen-Bollens \& Penry 2003, Gifford et al. 2007). This indirect methodology, which we have adapted for this study, allows for the inclusion of soft-bodied heterotrophic protists in the diet and the calculation of selectivity and ingestion rates for multiple prey taxa that the larvae would encounter in the field. To date there have been no studies investigating larval Pacific herring diet using methods that incorporate soft-bodied heterotrophic protists.

In this study our objectives were to experimentally determine i) what first feeding Pacific herring (Clupea pallasi) larvae consume using a natural assemblage of prey, ii) selectivity and iii) ingestion rates of the larvae on their prey. Pacific herring were chosen because they are of great ecological and economical value, but many populations are no longer a viable fishery resource due to overexploitation, predation pressure, and habitat degradation (Vdovin \& Chernoivanova 2006, Chimura et al. 2009). This study attempts to clarify the trophic pathways from lower planktonic food webs to higher trophic levels and to understand the implications of heterotrophic protists for larval fish feeding. 


\section{CHAPTER TWO}

\section{MATERIALS AND METHODS}

Larval herring feeding experiments. We conducted six feeding experiments in May and June of 2008 that examined the role of microplankton $(10-200 \mu \mathrm{m})$ in the diet of larval Pacific herring from Puget Sound, WA, using modified methods from Rollwagen-Bollens \& Penry (2003) and Gifford et al. (2007). We chose to define microplankton as 10-200 $\mu \mathrm{m}$ instead of the standard 20-200 $\mu \mathrm{m}$ range as this better reflects the size distribution of potential prey items in the experimental area. These experiments were conducted at the United States Geological Survey (USGS) Marrowstone Marine Field Station located in Nordland, Washington. Three of the experiments were conducted in May 2008, and another three experiments were conducted in June 2008. Experiments within each month were conducted within 24-48 hours of each other to minimize the effects of larval growth on feeding. In addition, three preliminary experiments were conducted in June 2007 that tested methodology, including appropriate prey density, predator density, and feeding conditions for the larvae. Larval herring used in all experiments were collected as embryos from Holmes Harbor, WA (May) and Cherry Point, WA (June) by the Washington Department of Fish and Wildlife. After hatching, larvae were housed in flow-through $760 \mathrm{~L}$ tanks that were supplied with filtered ambient seawater from Puget Sound (10-11 $\left.{ }^{\circ} \mathrm{C}\right)$, and were fed marine rotifers (Brachionus plicatilis), brine shrimp (Artemia franciscana) and concentrated algae (Isochrysis sp., Nannochloropsis sp.).

Seawater containing a natural assemblage of prey was collected from the surface off a nearby dock on Marrowstone Island. Twenty 1-L jars were covered with $200 \mu \mathrm{m}$ mesh and dipped into a bucket of freshly collected seawater. The 1-L jars were covered with duct tape on the sides in order to create contrast and enhance larval feeding, and the bottoms of the jars were 
left uncovered to allow for light penetration. In the laboratory, the contents of the jars were placed into a large bucket to homogenize the plankton. A 1-L subsample of seawater was filtered over a $73 \mu \mathrm{m}$ sieve and the sieve contents were enumerated under a dissecting microscope in order to ensure that the density of the plankton was appropriate for detecting a decrease in prey (based on preliminary experiments). This prey density range was approximately 100 metazoans $\mathrm{L}^{-1}$ in the $73-200 \mu \mathrm{m}$ size range. The 1-L jars were refilled with $500 \mathrm{ml}$ of the homogenized natural seawater and $500 \mathrm{ml}$ of filtered seawater that did not contain prey items, creating a 1:1 dilution of natural and filtered seawater, so as to attain the desired prey density. Two experimental jars served as "initial controls" and were preserved immediately (described below). Four jars served as "final control" chambers, and twelve jars served as "treatment" chambers. The treatments consisted of triplicate jars that contained 2, 4, 8, or 16 herring larvae. These four densities of herring larvae were used to ensure the detection of prey consumption, and not to detect predator density effects.

Larval herring (19-22 days post hatch, 11-13 $\mathrm{mm}$ ) were starved for fifteen hours prior to each experiment. Approximately 200 larvae were collected from the housing tanks and randomly sorted into twenty-four $30 \mathrm{ml}$ cups containing $10 \mathrm{ml}$ of seawater and no more than four larvae per cup to reduce crowding and stress. From the $30 \mathrm{ml}$ cups, the appropriate number of larvae (2-16, based on treatment) were placed into the 1-L chambers containing diluted seawater $\left(10.3^{\circ} \mathrm{C}, 29 \mathrm{psu}\right)$ under a combination of natural and fluorescent light $\left(1.8 \mu \mathrm{E} \mathrm{m} \mathrm{s}^{-1}\right)$. The mouth of each jar was covered with Parafilm to eliminate bubbles, capped, and placed on a rotating (1 rpm) plankton wheel in order to keep the plankton in suspension for the duration of each experiment. The jars were left to rotate on the plankton wheel for 6.5 hours. The incubation time was chosen based on preliminary experiments, direct feeding studies (Checkley 1982, Munk 
\& Kiorboe 1985), search volume (Munk \& Kiorboe 1985), and bioenergetics (Bollens 1988), to ensure that a detectable level of feeding would occur. At the end of the incubation period, the jars were removed from the plankton wheel and the seawater and larval herring were preserved. Larval herring were placed via pipette into small vials, anesthetized with MS-222, and preserved with $10 \%$ formalin.

Two methods were used for the preservation of seawater and plankton in the treatment and control chambers. To detect the presence of protist plankton $(10-200 \mu \mathrm{m}), 200 \mathrm{ml}$ of seawater from each chamber was preserved in 5\% acid lugol's solution. Larger metazooplankton (73-200 $\mu \mathrm{m}$ ) were separated from the remaining $800 \mathrm{ml}$ by filtration through a $73 \mu \mathrm{m}$ sieve and preserved in $10 \%$ formalin and filtered seawater solution.

Cell counts and biomass estimations. To enumerate protists in the lugol's preserved samples $(10-200 \mu \mathrm{m}), 10-15 \mathrm{ml}$ aliquots from each sample bottle were settled overnight in Utermöhl chambers. The entire contents of the chamber were enumerated using an Olympus CK40 inverted microscope at 200x magnification. Using an ocular micrometer, the size (length and width) and morphology (shape) of each prey item was recorded. Prey items were grouped into one of the following major prey categories: diatoms, dinoflagellates, aloricate ciliates, and loricate ciliates. Individuals were further placed into one of the following size categories; 10-30 $\mu \mathrm{m}, 30-73 \mu \mathrm{m}$, and 73-200 $\mu \mathrm{m}$. Individual cells of chain-forming diatom genera, such as Skeletonema, Thalassiosira, and Chaetoceros, were also enumerated and placed into the 10-30 $\mu \mathrm{m}$ size category.

To enumerate metazoans $(73-200 \mu \mathrm{m})$ in the formalin preserved samples, the entire contents of the sample jar were counted on a Leica MZ6 dissecting microscope at 10x magnification and prey items were grouped into the following categories: trochophores, bivalve 
larvae, rotifers, copepod nauplii, and gastropod larvae. The size and morphology of each prey item was recorded. Protist prey in these samples were not counted. Protist and metazoan prey density (cells ml ${ }^{-1}$ ) for each sample were combined. Biovolume for all prey types was calculated based on geometric shape (Hillebrand et al.1999), and carbon biomass was estimated using a biovolume-biomass conversion for the protist plankton (Menden-Deuer \& Lessard 2000) and the metazoan plankton (Yamaguchi et al. 2005).

Clearance and ingestion rate calculations. Clearance rates $\left(\mathrm{ml} \mathrm{larva}^{-1} \mathrm{~h}^{-1}\right)$ and ingestion rates $\left(\mu \mathrm{g} \mathrm{C} \operatorname{larva}^{-1} \mathrm{~h}^{-1}\right)$ were calculated using the equations of Marin et al. (1986). Clearance rates were calculated based on changes in prey abundance over the incubation, and ingestion rates were calculated based on the change in carbon biomass over the incubation. Negative clearance and ingestion rates were given a value of zero because negative clearance rates signified that the larval herring did not consume prey. Clearance rate is used here as a measure of selective feeding by the consumer (Frost 1972, Marin et al. 1986, Rollwagen-Bollens \& Penry 2003).

Data Analysis. Statistical analyses were conducted using SigmaStat 3.5. One-way ANOVA with equal variance tests (Levene's test) were conducted for each experiment and treatment to determine if there was a significant difference $(p<0.05$, Tukey 5 Multiple Range Test) between the number of cells in the final control and treatment bottles of each prey taxon and for total prey abundance. Our criteria for accepting any experiment as valid were 1) a significant reduction $(\mathrm{p}<0.05)$ in at least one prey taxon in any size category between final controls and treatments; and 2) the abundance of a significantly reduced group in the final controls contained a minimum of 5 cells $\mathrm{ml}^{-1}$. 
A two-way ANOVA with equal variances (Levene's test) was conducted on the grouped abundance data in order to determine if experiment, predator density, or an interaction between the two affected final prey abundance. Finally, one-way ANOVA tests were conducted on the clearance and ingestion rates for each prey type calculated from each treatment. A significant difference $(p<0.05)$ in clearance rates between any two or more prey categories within a treatment was interpreted as selective feeding by the fish larvae. 


\section{CHAPTER THREE}

\section{RESULTS}

Significant reductions $(\mathrm{p}<0.05)$ in major prey taxa, size classes within taxa, or size categories regardless of taxa were detected in six treatments within three of our experiments and were thus considered valid (Table 1). From this point forward, our results refer only to treatments within those three experiments. In experiment 1 , there was a significant decrease in total available prey regardless of taxa in the $73-200 \mu \mathrm{m}$ size category and a significant decrease in 73-200 $\mu \mathrm{m}$ dinoflagellates (Table 1). In experiment 2, there was a significant decrease in abundance of aloricate ciliates in two treatments, and of loricate ciliates in one treatment (Table 1). There was also a significant decrease in 30-73 $\mu \mathrm{m}$ aloricate ciliates (Table 1). In experiment 3, there was a significant decrease in abundance of bivalve larvae in two treatments (Table 1).

The results of the two-way ANOVA comparing total final prey abundance versus experiment and treatment (fish density) showed that final prey abundance was significantly different among valid experiments $(\mathrm{p}<0.001)$, but that treatment (fish density) did not significantly affect final prey abundance $(\mathrm{p}=0.991)$. The two-way ANOVA revealed that there was not a significant interaction between experiment and treatment among valid experiments. Therefore we concluded that final prey density was independent of the number of predators in each treatment, and predator density effects are therefore not discussed further. 


\begin{tabular}{|c|c|c|c|}
\hline & \multicolumn{3}{|c|}{ Experiment } \\
\hline Treatment & 1 & 2 & 3 \\
\hline 4 Herring & & $\begin{array}{c}\text { - aloricate } \\
\text { ciliates }\end{array}$ & $\begin{array}{c}\text { - bivalve } \\
\text { larvae }\end{array}$ \\
\hline 8 Herring & & $\begin{array}{c}\text { - loricate } \\
\text { ciliates }\end{array}$ & $\begin{array}{c}\text { - bivalve } \\
\text { larvae }\end{array}$ \\
\hline 16 Herring & $\begin{array}{c}\bullet 73-200 \text { um } \\
\text { dinoflagellates } \\
\cdot 73-200 \text { um } \\
\text { total prey }\end{array}$ & $\begin{array}{c}\text { - aloricate } \\
\text { ciliates } \\
\text {-30-70 aloricate } \\
\text { ciliates }\end{array}$ & \\
\hline
\end{tabular}

Table 1. Significant reductions in prey categories in treatments versus controls during larval herring feeding experiments. Experiments 1 \& 2 took place in May 2008 and experiment 3 took place in June 2008. 


\section{Available prey composition, size, abundance and biomass}

Available protist prey consisted of diatoms, dinoflagellates, aloricate ciliates, and loricate ciliates. Available metazoan prey consisted of trochophore larvae, bivalve larvae, rotifers, copepod nauplii, and gastropod larvae. A one-way ANOVA revealed that initial total prey abundance was not significantly different among experiments $(\mathrm{p}=0.095)$. The protist prey assemblage was three orders of magnitude higher in abundance (cells $\mathrm{ml}^{-1}$ ) than the metazoan assemblage (Fig. 1A). Total carbon biomass $\left(\mu \mathrm{g} \mathrm{C} \mathrm{ml}^{-1}\right)$ of the prey was not significantly different among experiments $(\mathrm{p}=0.100)$, and the majority of the biomass was from diatoms, dinoflagellates, aloricate ciliates, and copepod nauplii (Fig. 1B). Overall, the protist prey accounted for $99.9 \%$ of the mean abundance $\left(\right.$ cells $\left.\mathrm{ml}^{-1}\right)$ and $75.6 \%$ of the mean biomass $(\mu \mathrm{g} \mathrm{C}$ $\mathrm{ml}^{-1}$ ) for all experiments. 
A

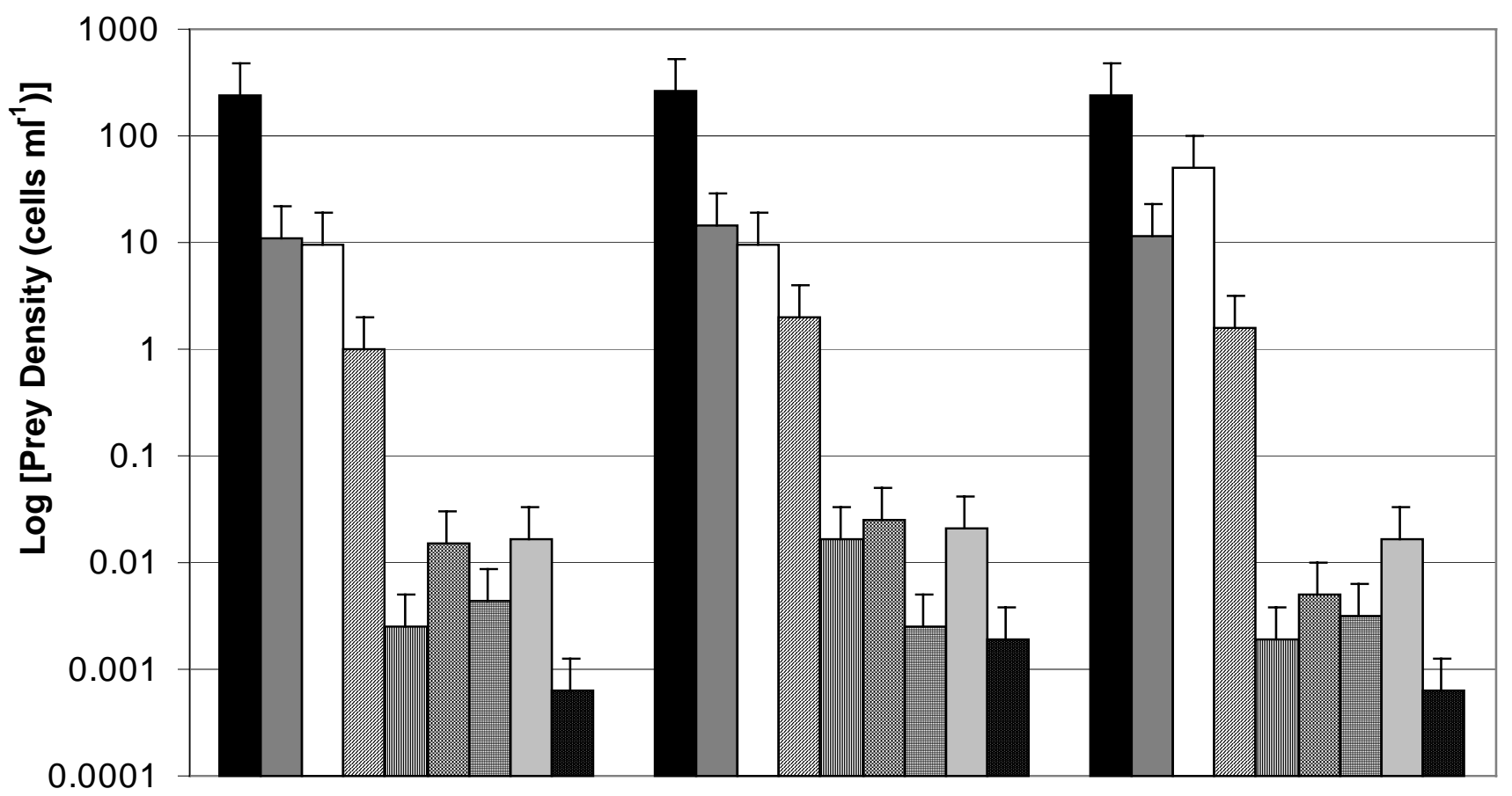

B

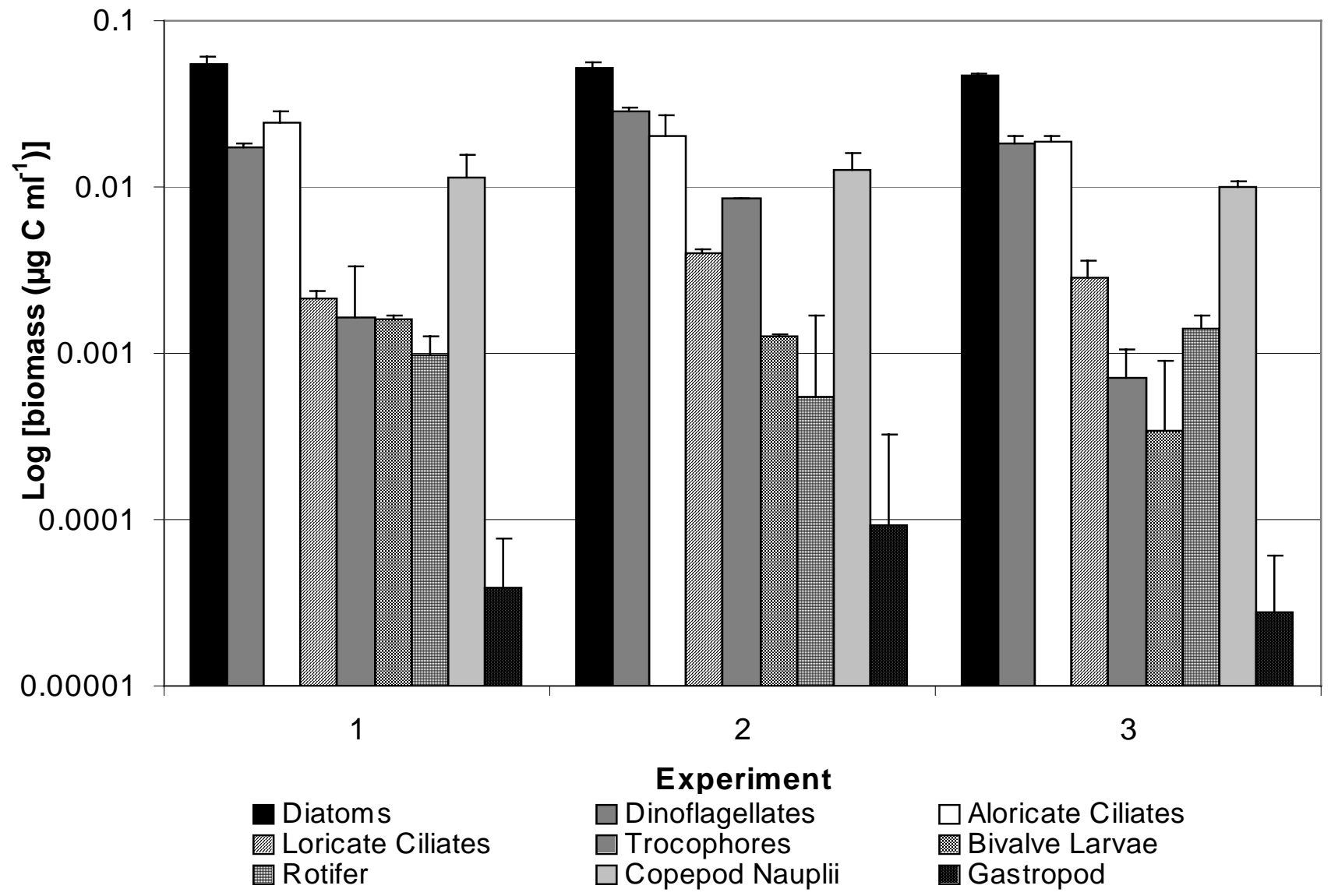


Figure 1. Mean initial prey density $\left(\right.$ cells $\left.\mathrm{ml}^{-1}, \mathrm{~A}\right)$ and carbon biomass $\left(\mu \mathrm{g} \mathrm{C} \mathrm{ml}{ }^{-1}, \mathrm{~B}\right)$ of prey available to the larval herring during feeding experiments. Experiments 1 and 2 took place in May 2008 and experiment 3 took place in June 2008.

\section{Clearance Rates}

\section{Selection based on prey taxonomic composition}

Clearance rates $\left(\mathrm{ml}\right.$ larva $\left.\mathrm{a}^{-1} \mathrm{~h}^{-1}\right)$ were used as a measure of prey selection in treatments within valid experiments. In experiment 1, copepod nauplii were cleared at a rate of $8.2 \pm 1.9 \mathrm{ml} \mathrm{larva}^{-1}$ $\mathrm{h}^{-1}$ while all other prey taxa were cleared at rates lower than $3 \mathrm{ml} \mathrm{larva} \mathrm{a}^{-1} \mathrm{~h}^{-1}$ (Fig. 2A), although no significant differences among clearance rates were calculated $(\mathrm{p}=0.160)$. In experiment 2 , aloricate and loricate ciliates were cleared at rates ranging from 2.1 to $15.2 \mathrm{ml} \mathrm{larva}^{-1} \mathrm{~h}^{-1}$ (Fig. 2B). In this experiment, no significant differences among clearance rates were observed $(\mathrm{p}=$ 0.124), suggesting that heterotrophic protists were selected for at rates comparable to those of metazoans in each of the three fish treatments. In experiment 3 , the highest clearance rates were calculated for bivalve larvae in two treatments (Fig. 2C), and the clearance rate for bivalve larvae in one treatment was significantly higher $(\mathrm{p}=0.025)$ than the clearance rates for other prey, suggesting strong selection for this prey taxon. However, no significant selectivity for any prey taxon was evident in the 8 herring treatment (Fig. 2C).

\section{Selection based on prey size}

Clearance rates were also used to assess prey selection among three size categories regardless of prey taxa: $10-30 \mu \mathrm{m}, 30-73 \mu \mathrm{m}$, and 73-200 $\mu \mathrm{m}$. In the two experiments in which prey within a size category were significantly reduced (Table 1), the ANOVA results showed that in experiment 1 , the $73-200 \mu \mathrm{m}$ prey were cleared at a rate significantly higher $(p=0.023)$ than the 10-30 $\mu \mathrm{m}$ and 30-73 $\mu \mathrm{m}$ categories (Fig. 3A), suggesting strong selection for 73-200 $\mu \mathrm{m}$ prey by the larval herring. In experiment 2 , no significant differences in clearance rates were calculated for prey within any size category $(p=0.095$, Fig. 3B). 
We also addressed larval herring selection on individual prey taxa within each size category. Positive clearance rates were observed on a variety of taxa within each size category, ranging from $0.7 \mathrm{ml} \mathrm{larva}^{-1} \mathrm{~h}^{-1}$ for diatoms to $10.4 \mathrm{ml} \mathrm{larva}^{-1} \mathrm{~h}^{-1}$ for dinoflagellates. However, in experiment 1 , no statistically significant differences in clearance rates were observed (Fig. 4A, p $=0.245)$. Similarly, in experiment 2 , there was no statistically significant difference among clearance rates for prey taxa based on size (Fig. 4B, $\mathrm{p}=0.192$ ). 

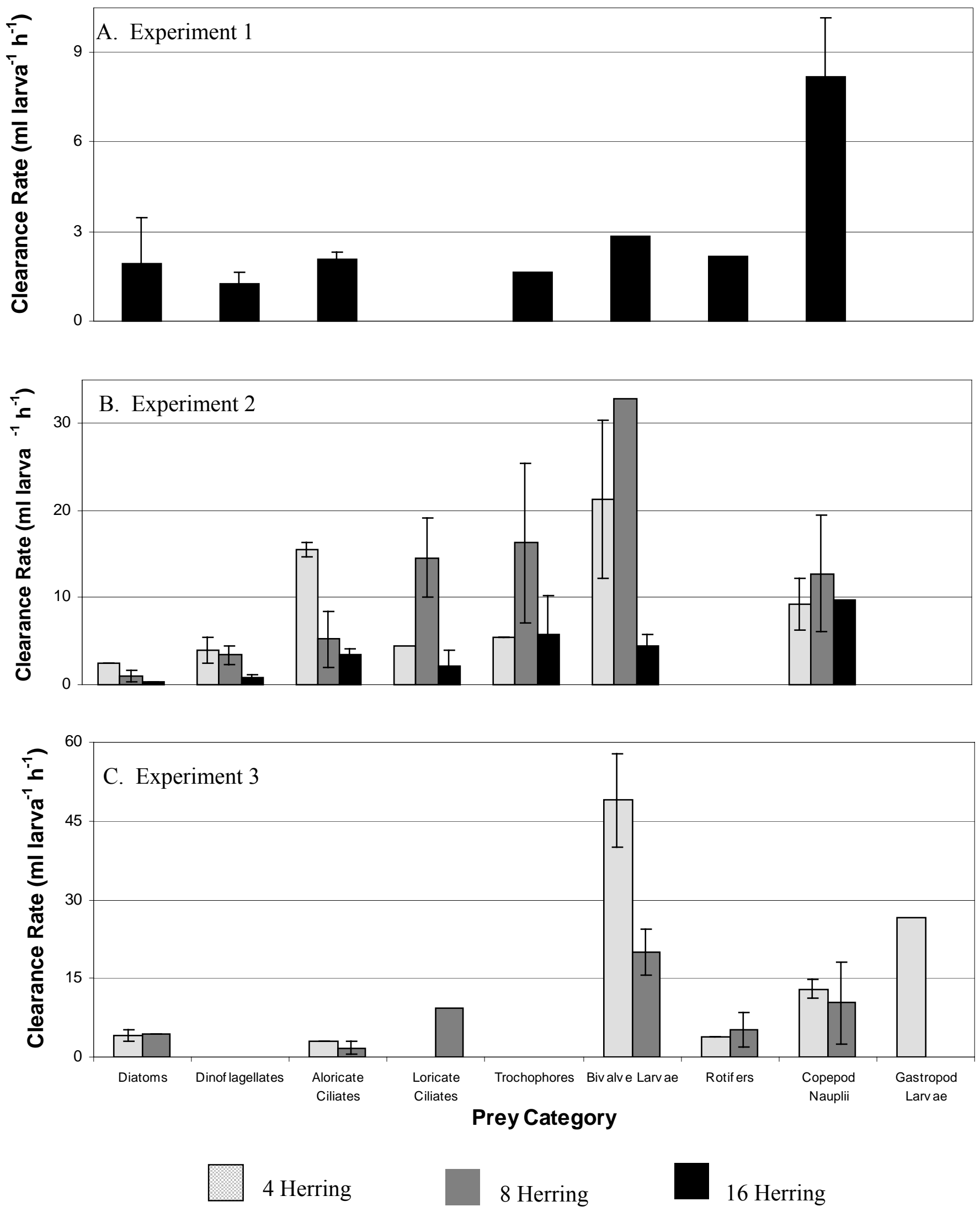

Figure 2. Clearance rates (ml larva-1 h-1) for prey taxa in experiment $1(\mathrm{~A})$, experiment 2 (B) and experiment $3(\mathrm{C})$ for treatments containing 4, 8 and 16 herring. Error bars $= \pm 1$ SE. 

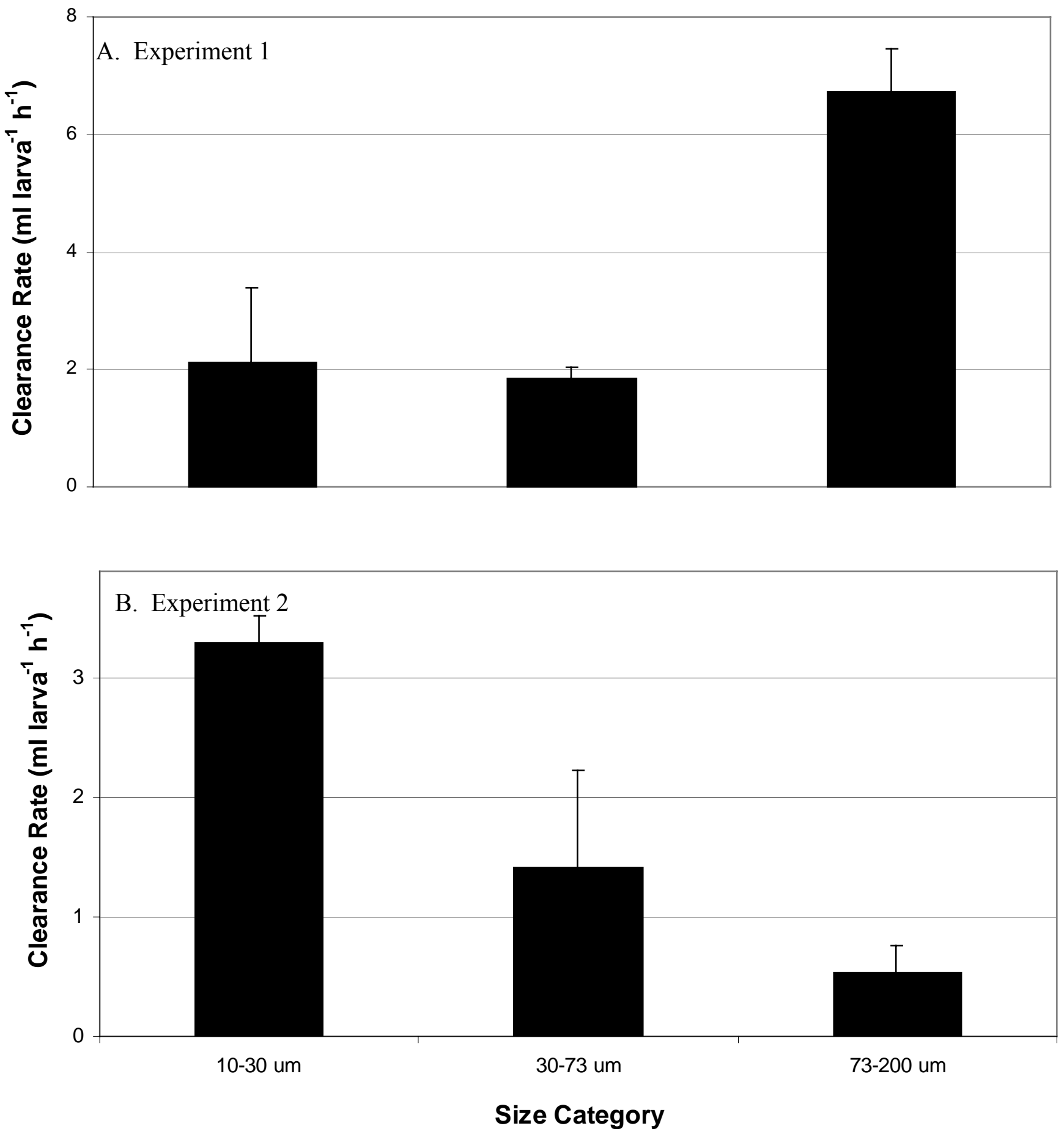

Figure 3. Clearance rates ( $\mathrm{ml}$ larva-1 h-1) for prey size categories in experiment 1 (A) and experiment 2 (B) in treatments containing 16 herring. Error bars $= \pm 1 \mathrm{SE}$. 

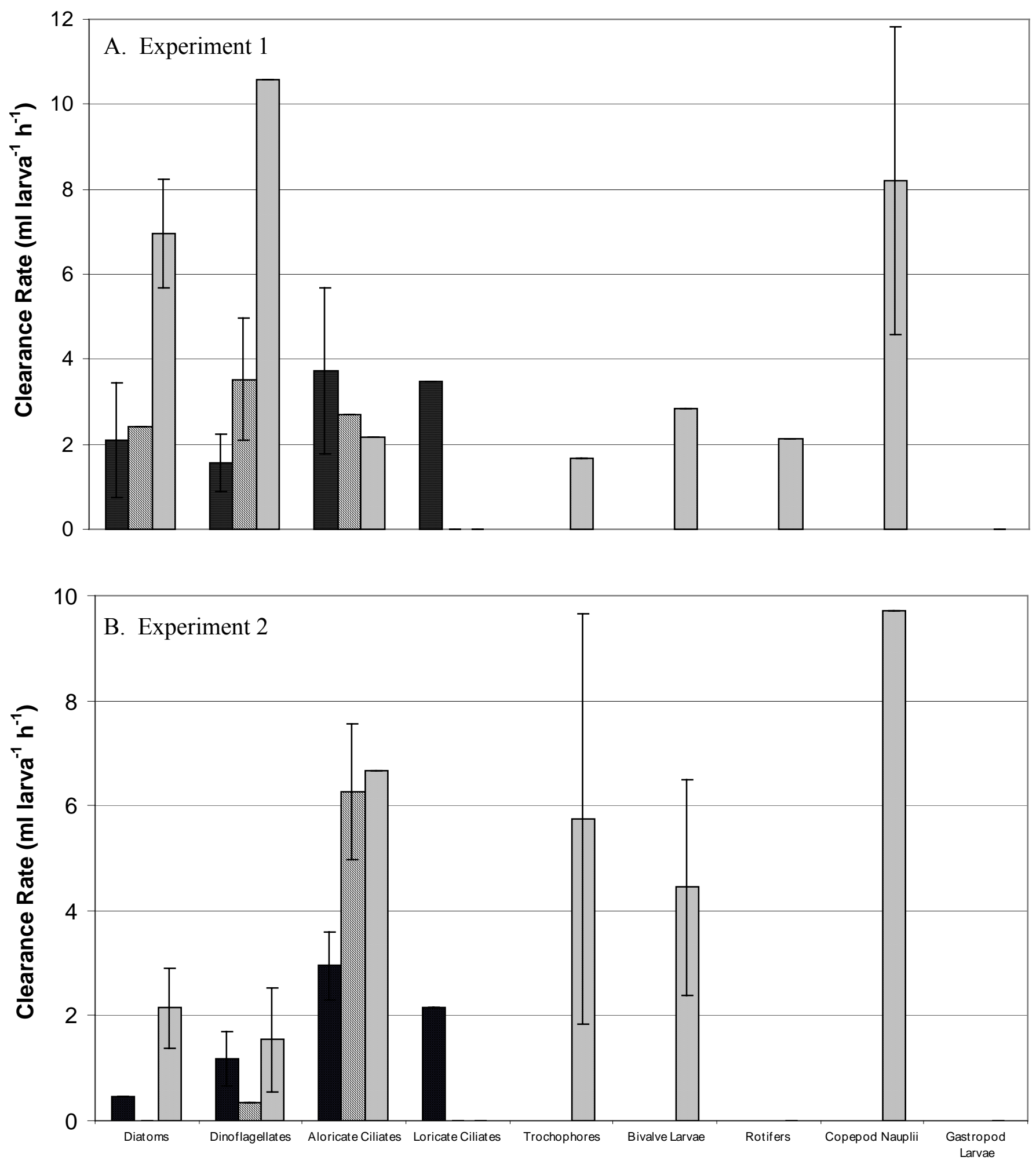

Prey Category

10-30 um $\square$ 30-73 um $\square 73-200$ um

Figure 4. Clearance rates ( $\mathrm{ml}$ larva-1 $\mathrm{h}-1)$ for taxa within size categories in experiment $1(\mathrm{~A})$ and experiment 2(B) in treatments containing 16 herring. Error bars $= \pm 1 \mathrm{SE}$. 


\section{Ingestion Rates}

\section{Major Prey Taxa}

Ingestion rates of carbon biomass $\left(\mu \mathrm{g} \mathrm{C} \operatorname{larva}^{-1} \mathrm{~h}^{-1}\right)$ were quantified in valid experiments. In experiment 1 , the ingestion rate for aloricate ciliates was significantly higher than other prey taxa $(p=0.028)$, suggesting that aloricate ciliates contributed a substantial amount of carbon to the larval herring diet (Fig. 5A). In experiment 2, aloricate ciliate carbon was ingested at rates comparable to copepod nauplii carbon in the eight and sixteen herring treatments, however in the four herring treatment, diatom carbon was ingested at a rate significantly higher $(p=0.039)$ than other prey taxa (Fig. 5B). In all treatments of experiment two, dinoflagellates, loricate ciliates, trochophores, and bivalve larvae carbon was ingested at rates close to zero (Fig. 5B). In experiment 3 , the ingestion rate for aloricate ciliates in the eight herring treatment was significantly higher than for loricate ciliates and other taxa $(p=0.033$, Fig. 5C).

\section{Prey Size}

Ingestion of carbon biomass based on prey size regardless of taxa was quantified for the three size categories: $10-30 \mu \mathrm{m}, 30-73 \mu \mathrm{m}$, and 73-200 $\mu \mathrm{m}$. In experiment 1 , ingestion rates for all three size categories were similar, and no significant differences among prey sizes were observed $(\mathrm{p}=0.124$, Fig. $6 \mathrm{~A})$. In experiment 2 , the ingestion rate for $73-200 \mu \mathrm{m}$ prey was significantly higher than rates for the other size categories $(p=0.038$, Fig. $6 B)$.

Ingestion rates for different prey taxa within the three size categories showed that in experiment 1 , protist and metazoan carbon were consumed at comparable (statistically indistinguishable) rates (Fig. 7A). In this experiment, diatom and dinoflagellate carbon were ingested at intermediate rates, while carbon from metazoans and loricate ciliates were ingested at low rates. In experiment 2 , the fish larvae consumed a broad range of prey types, as no 
significant differences in ingestion rates were observed for any particular prey taxon in any size category (Fig. 7B). 

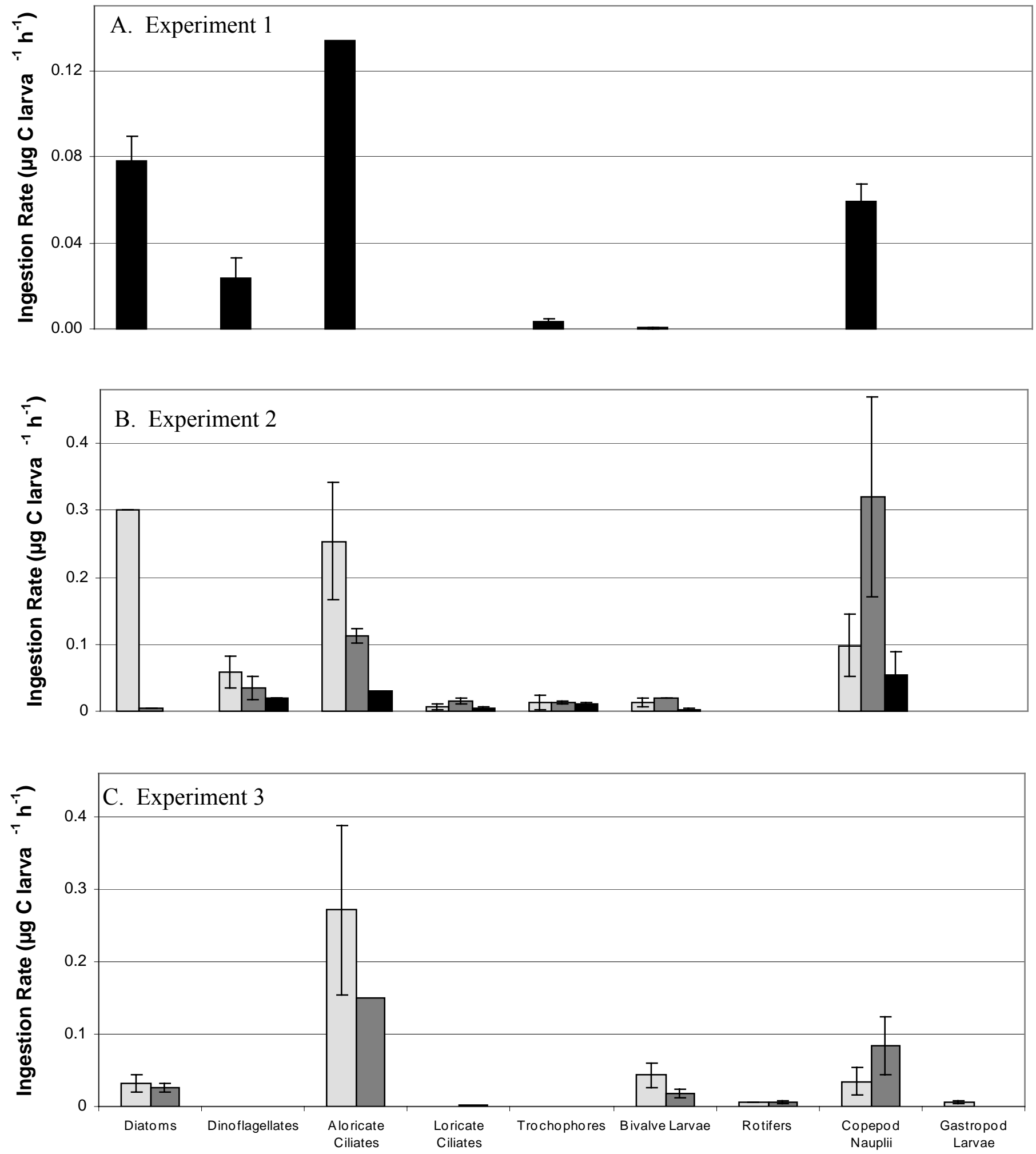

Prey Category

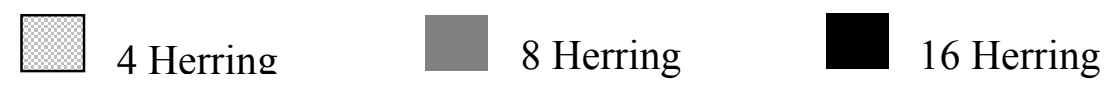

Figure 5. Ingestion rates ( $\mu \mathrm{g} \mathrm{C}$ larva-1 h-1) for prey taxa in experiment 1 (A) experiment 2 (B) and experiemnt $3(\mathrm{C})$ in treatments containing 4,8 and 16 herring. Error bars $= \pm 1 \mathrm{SE}$. 

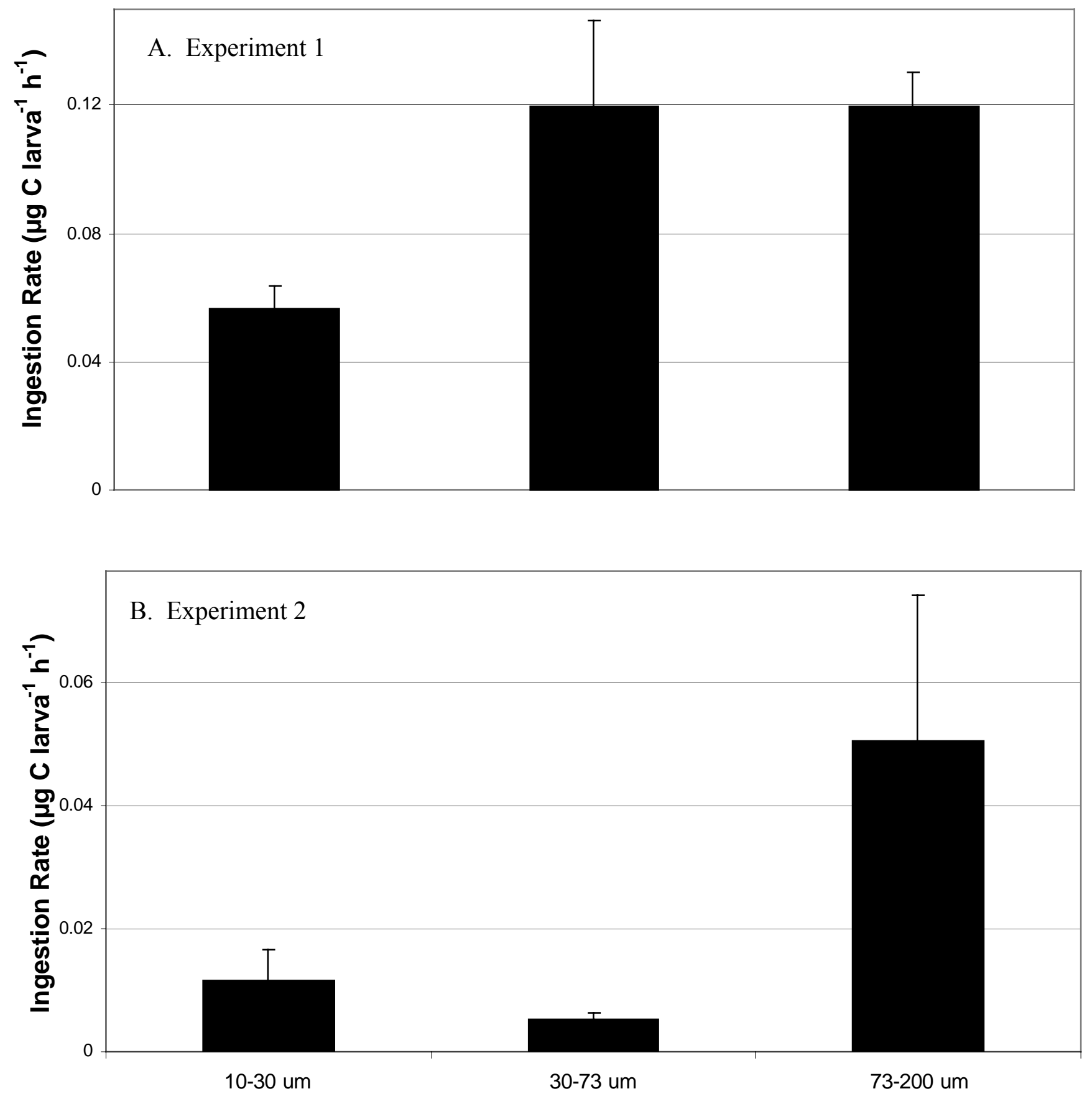

\section{Size Category}

Figure 6. Ingestion rates ( $\mu \mathrm{g} \mathrm{C}$ larva-1 h-1) for prey size in experiment $1(\mathrm{~A})$ and experiment 2 (B) in treatments containing 16 herring. Error bars $= \pm 1 \mathrm{SE}$. 

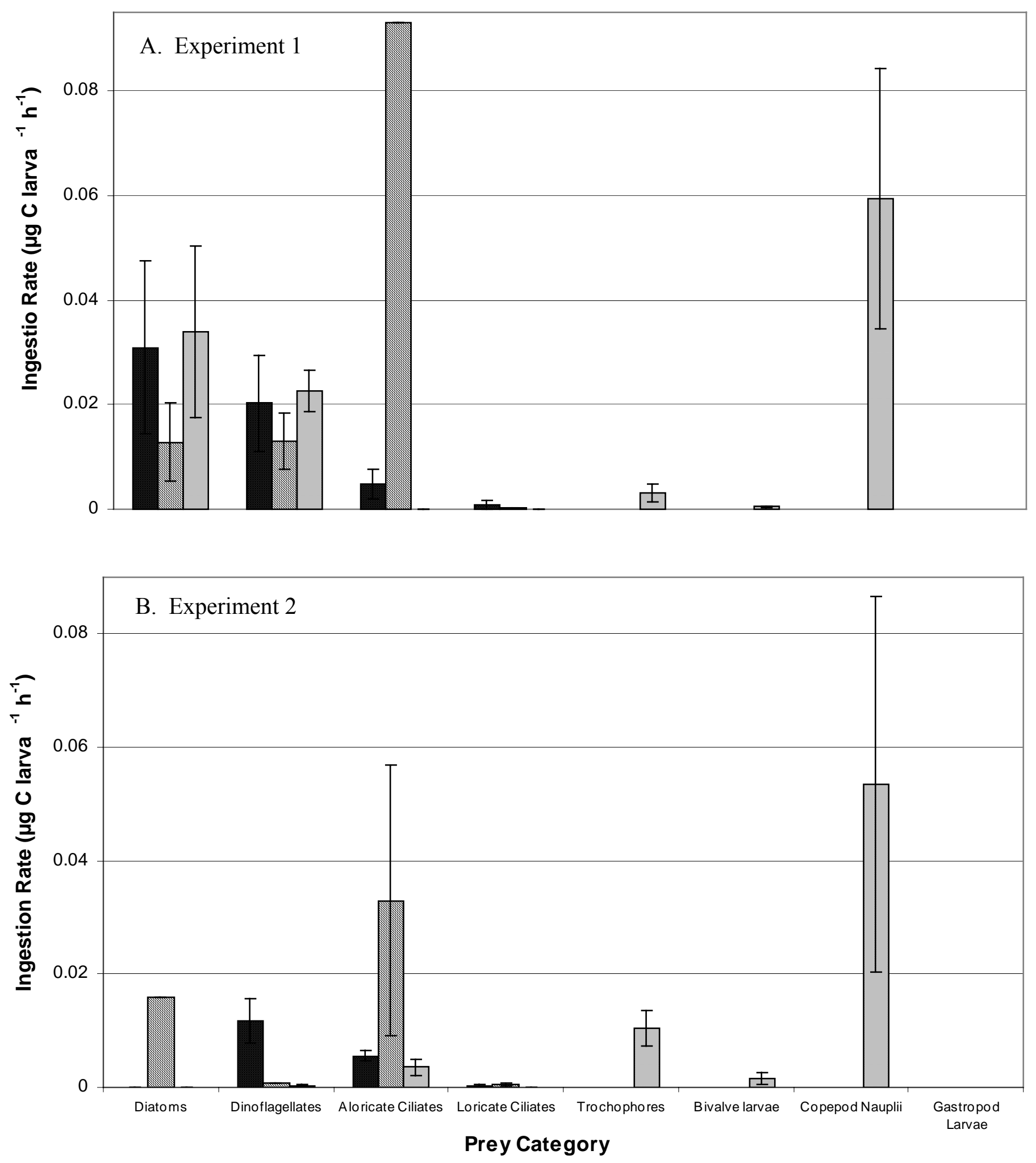

$\square$ 10-30 um $\square$ 30-73 um $\square 73-200$ um

Figure 7. Ingestion rates ( $\mu \mathrm{g} \mathrm{C}$ larva-1 h-1) for taxa within size categories in experiment $1(\mathrm{~A})$ and experiment 2(B) in treatments containing 16 herring. Error bars $= \pm 1 \mathrm{SE}$. 


\section{CHAPTER FOUR \\ DISCUSSION}

\section{Larval Herring Diet and Selectivity}

Although copepod nauplii and copepodites have traditionally been recognized as important in the diet of larval fish, the results of this study suggest that heterotrophic protists may contribute substantially to their diet as well. Previous diet studies have shown that larval fish may consume loricate ciliates (Last 1978a, b, Fukami et al. 1999, Bollens \& Sanders 2004, Figueiredo et al. 2005) and bivalve larvae (Checkley 1982), however to our knowledge there have been no studies that have found larval Pacific herring to feed on soft-bodied heterotrophic protists when larvae have been presented with the unaltered, natural assemblage of prey available in the field.

Studies that have examined soft-bodied heterotrophic protist prey items in the diet of larval fish have relied on modified gut analysis or observational methods in the laboratory. For instance, a study by Nagano et al. (2000) found a single taxon of cultured ciliates (Euplotes sp.) labeled with fluorescent microspheres in the guts of surgeonfish larvae (Paracanthurus hepatus), while unlabeled ciliates were never recognized in the gut contents. Similarly, Lessard et al. (1996) detected eight species of heterotrophic protists and four species of autotrophic protists that were live-stained with DAPI in the guts of larval Pollock (Theragra chalcogramma). Ohman et al. (1991) described predation of aloricate ciliates (Strombidium sp.) by first-feeding northern anchovy larvae by detection of protist-specific immunofluorescent antibody probes in the guts. Video observation also confirmed that larval Atlantic cod (Gadus morhua) prey upon a mono-culture of aloricate ciliates (Balanion sp.) (Hunt von Herbing \& Gallager 2000).

Larval fish feeding on protists has also been observed for larvae collected in the field. Fukami et al. (1999) used epifluorescence microscopy to detect DAPI-stained DNA of flagellate- 
like and ciliate-like cells in the guts of larval fish from 52 different taxonomic groups collected from Tosa Bay, Japan. In the Irish Sea, heterotrophic protists were estimated to be up to $35 \%$ of the Atlantic herring larvae diet, and 6-9\% for other fish larvae using methods that combined gut content analysis, field sampling of the plankton, and determination of prey accessibility (Figueiredo et al. 2005). In Conception Bay, Newfoundland, stable $\delta^{15} \mathrm{~N}$ isotopes were used to determine that larval flounder and capelin fed significantly on autotrophic and heterotrophic protists, which contrasted with stomach contents (Pepin \& Dower 2007). These estimates of protists in larval fish diet are higher than previous diet studies based on traditional methods that undersample protists. However, all of these studies rely on indirect methods to determine larval prey selection.

These studies were able to show that different species of larval fish from diverse geographical areas could consume soft-bodied heterotrophic protists, although these studies did not calculate prey preference using a selectivity index. If larval fish only have access to or are only able to consume one type of prey, they may be obligated to exploit that resource in order to survive. However, if larvae are presented with a variety of prey that includes phytoplankton, autotrophic and heterotrophic protists, copepod nauplii, and invertebrate larvae, then they may have the ability to discriminate between prey items. The methodology that we used in this study allowed us to determine not only diet composition of the larvae, but prey preference as well.

Clearance rate $\left(\mathrm{ml} \mathrm{larva}^{-1} \mathrm{~h}^{-1}\right)$ was used in this study as a measure of selectivity, and is conceptually known as the intensity of larval search for prey based on the volume of water that a larva 'cleared' of prey within a period of time (Frost 1972, Marin et al. 1986). The calculations are based on the ratio of prey abundance remaining in the final treatments to initial abundance, and also include cell growth in the absence of grazers in the controls (Rollwagen-Bollens \& 
Penry 2003). The resulting clearance rate therefore illustrates the impact of larval herring on their prey in relation to prey availability.

In two of our three valid experiments, clearance rates were not significantly different for protists and metazoans (Fig. 2A-B), indicating that larval herring did not select for "traditional" prey items, such as bivalve larvae and copepod nauplii, over protists. Herring are visual predators and may select food based on size, contrast and movement (Checkley 1982, Figueiredo et al. 2007). Thus bivalve larvae, although occurring in low concentrations, may have been consumed selectively in experiment 3 because of their larger size, slower movement, contrast, and minimal escape response. Furthermore, prey in the 73-200 $\mu \mathrm{m}$ size range may have also been selected over smaller prey items since larval fish tend to consume the largest spectrum of available prey that their gape can accommodate (Arrhenius 1996).

\section{Larval Preconditioning as a Source of Variation}

Although there were clear patterns of feeding by larval herring across our experiments, there was considerable variability in prey selectivity and ingestion rates. Initial prey abundance may influence the resulting variability in clearance and ingestion rates because ingestion generally increases as prey abundance increases (MacKenzie et al. 1990). However, initial prey abundance was not significantly different among experiments $(p=0.095)$, and therefore may not have influenced larval feeding rates. Variability may also be due to individual differences in the herring larvae, such as age, individual fitness, gape size, and body length. Hatching time and body length were averaged among individuals used in our experiments, and since larvae were chosen at random, there could be up to one day or $1 \mathrm{~mm}$ difference in hatching and length, respectively. Even though the larvae were housed under identical conditions prior to experiments, intra-cohort variability may determine individual feeding success and fitness 
(Hillgruber \& Kloppmann 2001). Additionally, experiments conducted in May and June used herring larvae from different spawning stocks, which may have also introduced variability between experiments.

Another potential cause of variability in feeding in our experiments was preconditioning of the larvae to their prey. Feeding success of larval fish increases if they have been previously exposed to the prey type (Dutton 1992), and the larvae used in this study were not preconditioned to a natural assemblage of prey. However, the larvae were reared on a mixed diet of Artemia nauplii, rotifers, and algae. The movement and escape responses of these prey items are comparable to copepod nauplii, heterotrophic protists, and diatoms (which lack an escape response), respectively, and therefore this may have allowed the larvae to recognize these prey items. Preconditioning the larvae to an even more diverse assemblage of prey prior to the experiments may have increased feeding and thus the number of significant results.

\section{Larval Herring Ingestion}

While clearance is a measure of selectivity, ingestion rates $\left(\mu \mathrm{g} \mathrm{C} \operatorname{larva}^{-1} \mathrm{~h}^{-1}\right)$ may better reflect potential growth and survival of predators. The ingestion rates calculated in this study suggest that although metazoans may contribute a substantial amount of carbon to the diet of larval herring, heterotrophic protists may provide comparable amounts, and in some cases the majority of carbon ingested (Fig. 5). Therefore, the consumption of protists may play a crucial role in fulfilling the metabolic requirements of larval herring, and may contribute to their growth and increase their chance of survival. Previous studies that have investigated larval fish ingestion of ciliates have indicated that larvae are able to detect and ingest ciliates in lower densities than those found in marine environments $\left(<20\right.$ ciliates $\left.\mathrm{ml}^{-1}\right)$. For example, in the Irish Sea, naked and tintinnid ciliates were rare in the field but were detected in the diet of larval fish 
(Figueiredo et al. 2007). Furthermore, larval fish must consume about $20 \%$ of body carbon day ${ }^{-1}$ to sustain growth, and the upper density range of ciliates in the field may be high enough to meet this requirement (Lynn \& Montagnes 1991, Figueiredo et al. 2007).

It is important to recognize the limitations of small-scale incubations compared to field conditions. Larvae reared in the laboratory require higher densities of food to grow, and ingestion rates in the laboratory are most likely affected primarily by time spent on handling of the prey, including pursuit, capture, consumption, and failed feeding attempts (Houde 1977, MacKenzie et al. 1990). Edge effects may also affect feeding. In highly restrictive environments, such as the 1 -L chambers used in this experiment, larvae may spend up to $50 \%$ of the time at the tank wall (Munk \& Kiroboe 1985). Lighting in laboratory conditions can also be a source of variation, as irradiance affects the ability of the larvae to see their prey (Browman et al. 2005). In the field, ingestion rates may be affected by different factors, such as prey distribution and composition, turbulence, and other environmental conditions (Fiksen \& Folkvord 1999). Therefore, the ingestion rates calculated in this study may not be directly applicable to field conditions (Rothschild \& Osborn 1988), and we recommend further studies in order to determine feeding dynamics of larval fish in the field.

It is also important to note the differences between direct and indirect feeding studies. The methods used in our study indirectly determined feeding events because we enumerated prey items in the seawater and not directly in the guts of the larvae. Indirect methods of feeding detection assume that prey growth is consistent with and without predators (Lessard et al. 1996), and the short incubation times used in our study are consistent with this. 


\section{Implications and Summary}

Larval fish are often food limited in nature due to the abundance and distribution of their prey (Fiksen \& Foldvord 1999). However, the abundance of heterotrophic protists has been underestimated or not considered in previous diet studies, and thus there may be more food available to larval fish than previously recognized (Figueiredo et al. 2005). Gut content analyses that have included heterotrophic protists in the diet by finding lorica of tintinnids or thecate dinoflagellates in field-collected larvae have overlooked the fact that naked heterotrophic protists occur in larger numbers (Nagano et al. 2000, Bollens and Sanders 2004). Protists are a potentially significant food source for larval fish due to their high abundance, biomass, growth rates, turnover, and relative homogeneity (Pierce \& Turner 1992, Lessard et al. 1996, RollwagenBollens et al. 2006). The available biomass of heterotrophic protists is on the same order of magnitude as that of copepod nauplii, and they have greater growth and turnover rates (Fukami et al. 1999). Additionally, in some areas there may be a stronger correlation between the spatial distribution of fish larvae and heterotrophic protists than with copepod nauplii and eggs (Lasker et al. 1970, Zhang et al. 2002) because many metazoan zooplankton are patchy in their distribution and exhibit strong diel vertical migration (Young et al. 2009).

Although prey distribution and abundance is important for larval fish, food limitation is regulated by multiple variables and is not the result of prey density alone (Leggett \& Deblois 1994). In order to enhance larval survival and alleviate food limitation, the consumption of heterotrophic protists must offset energy expenditure and meet metabolic requirements. The consumption of heterotrophic protists by larval fish may be less energetically expensive than the consumption of copepod nauplii, even though the net energy gain from the capture of a nauplius is two orders of magnitude higher than for the capture of a heterotrophic protist (Hunt von 
Herbing et al. 2001). Additionally, consumption of both loricate and aloricate ciliates may enhance survivability of fish larvae in the absence of larger, more nutritious prey items (Nagano et al. 2000).

Although consumption of heterotrophic protists may fulfill energy demands, inadequate nutritional value of prey can also cause starvation mortality. Larval fish require various highly unsaturated fatty acids (HUFA), phospholipids, inositol and choline in specific amounts and ratios in order for growth, survival, and metamorphosis to occur (Sargent et al. 1999). Calanoid copepods provide fairly ideal amounts of these nutrients to the larval fish diet, but it is unclear whether heterotrophic protists alone could provide sufficient amounts for long-term growth and survival. Heterotrophic and mixotrophic dinoflagellates are capable of biochemically upgrading food, producing essential fatty acids and/or sterols which may be absent in bacteria and phytoplankton, while marine ciliates only repackage their food and do not add value to it (Klein Breteler et al. 1999), making them adequate only as an intermediary source of food for fish larvae. But, this intermediary food source could be crucial for larval survival because during early stages of development, larval fish may not be able to fully digest copepods and nauplii (O'Connell 1981). Although nutrient-dense prey items are essential to the diet of larval fish, heterotrophic protists may serve as an optimal intermediary food source if nutrient-dense prey items are unavailable.

Recent studies in which heterotrophic protists are included in the available prey for larval fish reveal certain food web dynamics that had been previously overlooked. Heterotrophic protists provide a link between the microbial loop and metazoans, comprise a significant part of the mesoplankton diet, and are the primary grazers of phytoplankton and bacteria (e.g., Porter et al. 1985, Pierce \& Turner 1992, Rollwagen-Bollens et al. 2006). Our study demonstrates a direct 
link between heterotrophic protists and higher trophic levels, such as larval herring. This traditionally unrecognized trophic pathway may create a more efficient transfer of energy from lower trophic levels to planktivorous fish species, potentially increasing larval fish growth and survival. This may ultimately influence recruitment success because a small decrease in mortality may significantly affect year-class strength (Houde 1987).

In summary, this study examined feeding dynamics of larval Pacific herring on natural assemblages of prey with the inclusion of soft-bodied protists. We found that when presented with a natural assemblage of prey, larval herring consumed aloricate ciliates, loricate ciliates, and dinoflagellates, even in the presence of metazoan prey. We also found that ingestion of carbon biomass from heterotrophic protists was of the same magnitude, and in some cases exceeded, ingestion of metazoan carbon. These results suggest that protists may be more important in the diet of larval fish than previously recognized, and confirm that there is a direct trophic link between heterotrophic protists and larval fish, which may have implications for larval growth, survival and subsequent recruitment success. 


\section{REFERENCES}

Arrhenius F (1996) Diet composition and food selectivity of 0-group herring (Culpea harengus L. and sprat (Sprattus sprattus (L.)) in the northern Baltic Sea. J Mar Sci 53:701-712

Arthur DK (1976) Food and feeding of larvae of three fishes occurring in the California Current, Sardinops sagax, Engraulis mordax, and Trachurus symmetricus. Fish Bill US 74: 517530

Bollens SM (1988) A model of predatory impact of larval marine fish on the population dynamics of their zooplankton prey. J Plankton Res 10:887-906

Bollens SM, Sanders A (2004) Ecology of larval Pacific herring Clupea pallasi in the San Francisco Estuary: Seasonal and interannual abundance, distribution, diet and condition. Amer Fish Soc Symp 36:15-35

Browman HI, Skiftesvik AB, Kuhn P (2005) The relationship between ultraviolet and polarized light and growth rate in the early larval stages of turbot (Scophtalmus maximus), Atlantic cod (Gadus morhua) and Atlantic herring (Clupea harengus) reared in intensive culture conditions. Aquaculture 256:296-301

Checkley DM (1982) Selective Feeding by Atlantic Herring (Clupea harengus) Larvae on Zooplankton in Natural Assemblages. Mar Ecol Prog Ser 9:245-253

Chimura M, Watanabe Y, Okouchi H, Shirafuji N, Kawamura T (2009) Hatch perioddependent early growth and survival of Pacific herring Clupea pallasii in Miyako Bay, Japan. J Fish Biol 74:604-620

Cushing DH (1975) Marine ecology and fisheries. University Press, Cambridge

Dutton P (1992) Effects of experience on feeding success by larval white seabass Atractoscion nobilis. J Fish Biol 41:765-773

Figueiredo GM, Nash RDM, Montagnes DJS (2005) The role of the generally unrecognized microprey source as food for larval fish in the Irish Sea. J Mar Biol 148:395-404

Figueiredo GM, Nash RDM, Montagnes DJS (2007) Do protozoa contribute significantly to the diet of larval fish in the Irish Sea? J Mar Biol Ass UK 87:843-850

Fiksen O, Foldvord A (1999) Modelling growth and ingestion process in herring Clupea harengus larvae. Mar Ecol Prog Ser 184:273-289

Frost BW (1972) Effects of size and concentration of food particles on the feeding behavior of the marine planktonic copepod Calanus pacificus. Limnol Oceanogr 6:805-815 
Fukami K, Watanabe A, Fujita S, Yamaoka K, Nishijima T (1999) Predation on naked heterotrophic protist microzooplankton by fish larvae. Mar Ecol Prog Ser 185:285-291

Gifford SM, Rollwagen-Bollens GC, Bollens SM (2007) Mesozooplankton omnivory in the upper San Francisco estuary. Mar Ecol Prog Ser 348:33-46

Hillebrand HH, Dürselen CC, Kirschtel D, Pollingher U, Zohary T (1999) Biovolume calculation for pelagic and benthic microalgae. J Phycol 35:403-424

Hillgruber N, Kloppmann M (2001) Small-scale patterns in distribution and feeding of Atlantic mackerel (Scomber scombrus L.) larvae in the Celtic Sea with special regard to intra-cohort cannibalism. Helgol Mar Res 55(2):135-149

Hjort J (1914) Fluctuations in the great fisheries in Northern Europe viewed in light of biological research. Rapp Congr CIESM 20:1-228

Houde ED (1977) Effects of stocking density and food density on survival, growth, and yield of laboratory-reared larvae of red sea bream, Archosargus rhomboidalis (L.) (Sparidae). J Fish Biol 7: 115-127

Houde ED (1987) Fish early life dynamics and recruitment variability. Am Fish Soc Symp 2: 17-29

Houde ED (1989) Comparative growth, mortality and energetics of marine fish larvae: temperature and implied latitudinal effects. Fish Bull US 87: 471-495

Hunt von Herbing I, Gallager SM (2000) Foraging behavior in early Atlantic cod larvae (Gadus morhua)feeding on a heterotrophic protist (Balanion sp.) and a copepod nauplis (Pseudodiaptomus sp.). Mar Biol 136:591-602

Hunt von Herbing I, Gallager SM, Halteman W (2001) Metabolic costs of pursuit and attack in early larval Atlantic cod. Mar Ecol Prog Ser 216:201-212

Klein Breteler WCM, Schogt N, Baas M, Schouten S, Kraay GW (1999) Trophic upgrading of food quality by heterotrophic protists enhancing copepod growth: role of essential lipids. Mar Biol 135: 191-198

Lasker, R (1975) Field criteria for the survival of anchovy larvae: the relation between inshore chlorophyll maximum layers and successful first feeding. Fish Bull US 73:453-462

Lasker R, Feder HM, Theilacker GH, May RC (1970) Feeding, growth and survival of Engraulis mordax larvae reared in the laboratory. Mar Biol 5:345-353

Last JM (1978a) The food of four species of pleuronecteform larvae in the eastern English Channel and southern North Sea. Mar Biol 45: 359-368 
Last JM (1978b) The food of three species of gadoid larvae in the eastern English Channel and southern North Sea. Mar Biol 48: 377-386

Leggett WC, Deblois E (1994) Recruitment in marine fishes: is it regulated by starvation and predation in the egg and larval stages? Neth J Sea Res 32:119-134

Lessard EJ, Martin MP, Montagnes DJS (1996) A new method for live-staining protists with DAPI and its application as a tracer of ingestion by walleye Pollock (Theragra chalcogramma (Passas)) larvae. J Exp Mar Biol Ecol 204: 43-57

Lynn DH, Montagnes DJS (1991) Global production of heterotrophic marine planktonic ciliates. In Protozoa and their role in marine processes (ed. PC Reid et al.), 281-307

MacKenzie BR, Leggett WC, Peters RH (1990) Estimating larval fish ingestion rates: can laboratory values be reliably extrapolated to the wild? Mar Ecol Prog Ser 67: 209-225

Marin V, Huntley ME, Frost B (1986) Measuring feeding rates of pelagic herbivores: analysis of experimental design methods. Mar Biol 93:49-58

Menden-Deuer S, Lessard EJ (2000) Carbon to volume relationships for dinoflagellates, diatoms, and other protist plankton. Limnol Oceanogr 45:569-579

Munk P, Kiorboe T (1985) Feeding behaviour and swimming activity of larval herring (Clupea harrengus) in relation to density of copepod nauplii. Mar Ecol Prog Ser 24: 15-21

Nagano N, Iwatsuki Y, Kamiyama T, Nakata H (2000) Effects of marine ciliates on survivability of the first-feeding larval surgeonfish, Paracanthurus hepatus: laboratory rearing experiments. Hydrobiologie 432: 149-157

O’Connell CP (1981) Development of organ systems in the Northern Anchovy, Engraulis mordax, and other teleosts. Am Zool 21: 429-446

Ohman MD, Theilacker GH, Kaupp SE (1991) Immunochemical detection of predation on ciliates protists by larvae of the northern anchovy (Engraulis mordax). Biol Bull 181:500-504.

Pepin P, Dower JF (2007) Variability in the trophic position of larval fish in a coastal pelagic ecosystem base on stable isotopic analysis. J Plankton Res 29(8):727-737

Pierce RW, Turner JT (1992) Ecology of planktonic ciliates in marine food webs. Rev Aquat Sci 6(2):139-181

Porter KG, Sherr EB, Sherr BF, Pace M, Sanders RW (1985) Protozoa in planktonic food webs. J Protozool 32(3):409-415 
Reitan KI, Natyik CM, Vadstein O (1998) Drinking rate, uptake of bacteria and microalgae in turbot larvae. J Fish Biol 53(6): 1145-1154

Rollwagen-Bollens GC, Penry DL (2003) Feeding dynamics of Acartia spp. Copepods in a large, temperate estuary (San Francisco Bay, CA). Mar Ecol Prog Ser $257: 139-158$

Rollwagen-Bollens GC, Bollens SM, Penry DL (2006) Vertical distribution of micro- and nanoplankton in the San Francisco Estuary in relation to hydrography and predators. Aquat Microb Ecol 44:4:143-163

Rossi S, Sabates A, Latasa M, Reyes E (2006) Lipid biomarkers and trophic linkages between phytoplankton, zooplankton and anchovy (Engraulis encrasicolus) larvae in the NE Mediterranean. J Plankton Res 28: 551-562

Rothschild BJ, Osborn TR (1988) Small-scale turbulence and plankton contact rates. J Plankton Res 10: 465-474

Sargent J, McEvoy L, Estevez A, Bell G, Bell M, Henserson J, Tocher D (1999) Lipid nutrition of marine fish during early development: current status and future directions. Aquaculture 179:217-229

Spittler P, Brenning U, Arlt G (1990) Heterotrophic protists- the First Food of Larval Herring (Clupea harengus L.)? Int Rev Gesamten Hydrobiol 75:597-603

Stoecker DK, Capuzzo JM (1990) Predation on protozoa: its importance to zooplankton. J Plankton Res 12:891-908

Vdovin AN, Chernoivanova LA (2006) Long-term dynamics of certain parameters of Pacific herring Clupea pallasiis (Clupeidae) in Peter the Great Bay. J Ichthyol 46(1):5057

Yamaguchi A, Watanabe Y, Ishidi H, Harimoto T, Maeda M, Ishizaka J, Ikeda T, Takahashi MM (2005) Biomass and Chemicals composition of net-plankton down to greater depths (0-5800m) in the western North Pacific Ocean. Deep-Sea Res 52:341-353

Young KV, Dower JF, Pepin P (2009) A hierarchical analysis of the spatial distribution of larval fish prey. J Plankton Res 31(6):687-700

Zhang W, Xu K, Wan R, Zhang G, Meng T, Xiao T, Wang R, Sun S, Choi JK (2002) Spatial distribution of ciliates, copepod nauplii and eggs, Engraulis japonicus post-larvae and microzooplankton herbivorous activity in the Yellow Sea, China. Aquat Microb Ecol 27(3): 249-259 